\title{
REORIENTASI VISI PEMBELAJARAN MATEMATIKA SEKOLAH (Implikasi Teori Kecerdasan Majemuk Gardner dalam Praktik Pembelajaran Matematika di Sekolah)
}

\author{
Abdul Halim Fathani \\ Program Studi Pendidikan Matematika Universitas Islam Malang \\ ah.fathani@gmail.com
}

\begin{abstract}
Abstrak
Sejak peradaban manusia bermula, matematika memainkan peranan yang sangat vital dalam kehidupan sehari-hari. Di sisi lain, praktik pendidikan matematika di Indonesia masih memiliki tantangan untuk meningkatkan gairah (semangat dan motivasi) belajar matematika bagi siswa. Salah satu pendekatan humanis yang dapat diimplementasikan adalah menggunakan paradigma pembelajaran berdasarkan teori kecerdasan majemuk yang digagas Gardner. Penerapan pembelajaran dengan menggunakan pendekatan kecerdasan majemuk ini diharapkan siswa dapat belajar secara bermakna. Dengan kata lain, siswa dapat mempelajari matematika dengan mengoptimalkan potensi kecerdasan yang dimilikinya. Dengan mengoptimalkan gaya belajar yang dipengaruhi oleh tingkat kecerdasan majemuk, siswa dapat terlibat secara aktif dalam proses pembelajaran matematika, siswa lebih dapat menunjukkan kelebihan dan keunikan yang dimilikinya sehingga siswa merasa lebih dihargai yang akhirnya dapat meningkatkan kepercayaan diri dan menimbulkan rasa tanggungjawab siswa dalam proses pembelajaran matematika.
\end{abstract}

Kata Kunci: Pembelajaran, Matematika, Kecerdasan Majemuk, Keunikann Individu

\section{PENDAHULUAN}

Tantangan dunia pendidikan semakin kompleks. Salah satu isu besar yang harus dihadapi pada tahun 2016 ini adalah pemberlakuan Masyarakat Ekonomi Asean (MEA). Pemberlakuan MEA ini dapat dijadikan sebagai momentum yang baik dalam rangka melakukan perbaikan-perbaikan di pelbagai sektor, terutama sektor pendidikan di Indonesia agar mampu menghasilkan sumber daya manusia (SDM) berkualitas yang memiliki daya saing tinggi.

Murtiyasa (2015:28) mempertegas bahwa dalam memasuki era masyarakat ekonomi asean (MEA) 2015, stakeholder Indonesia tentu harus mengikuti standar internasional supaya dapat tetap survive di era global ini. Demikian halnya dunia pendidikan, termasuk pendidikan matematika, harus mampu berprestasi di dunia internasional.Tetapi sayangnya dari waktu ke waktu kemampuan matematika di forum internasional tidak segera beranjak baik. Hal ini 
terlihat dari beberapa hasil survei yang dilakukan oleh lembaga-lembaga internasional seperti Trend in International Mathematics and Science Study (TIMSS) dan Program for International Student Assessment (PISA) yang menempatkan Indonesia pada posisi yang belum menggembirakan di antara negara-negara yang disurvei.

Lebih lanjut, Murtiyasa (2015:28) merinci data hasil survei tersebut. Survei TIMSS, dilakukan setiap 4 tahun dengan mengambil fokus pada domain isi matematika dan kognitif siswa ini, pada tahun 1999 menempatkan Indonesia pada posisi 34 dari 48 negara, tahun 2003 pada posisi 35 dari 46 negara, tahun 2007 pada posisi 36 dari 49 negara, dan pada tahun 2011 pada posisi 36 dari 40 negara. Sementara itu studi tiga (3) tahunan PISA, yang bertujuan untuk mengetahui literasi matematika siswa ini, pada tahun 2000 menempatkan Indonesia pada posisi 39 dari 41 negara, tahun 2003 pada posisi 38 dari 40 negara, tahun 2006 pada posisi 50 dari 57 negara, tahun 2009 pada posisi 61 dari 65 negara, dan yang terakhir tahun 2012 pada posisi 64 dari 65 negara.

Di sisi lain, praktik pendidikan matematika di Indonesia masih memiliki tantangan untuk meningkatkan gairah (semangat dan motivasi) belajar matematika bagi siswa. Terdapat pelbagai pertanyaan yang masih menghantui dunia pendidikan matematika. Seperti pertanyaan: "Mengapa saya harus belajar matematika?", "Untuk apa belajar matematika?", "Apa kelebihan matematika, sehingga harus dipelajari bahkan menjadi salah satu pelajaran yang di-ujian nasional-kan?", dan masih banyak pertanyaan lainnya yang pada intinya mempertanyakan "fungsi" belajar matematika. Pelbagai pertanyaan tersebut muncul ketika beberapa orang dianjurkan dengan paksa ataupun tidak paksa untuk belajar Matematika ketika di bangku sekolah. Bisa saja, pertanyaan itu muncul sebagai wujud konkret dari kekritis-an seseorang siswa atas praktik pembelajaran matematika yang terjadi selama ini. Atau, justru muncul sebagai refleksi atas ke-apatis-an seseorang siswa terhadap Matematika, karena mereka belum "memperoleh" sesuatu dari matematika?

Sebagian pihak berargumen bahwa pembelajaran matematika di sekolah Indonesia, sejauh ini masih didominasi oleh pembelajaran konvensional dengan paradigma mengajarnya. Siswa diposisikan sebagai “obyek", siswa dianggap tidak tahu atau belum tahu apa-apa, siswa dianggap seperti gelas kosong yang harus diisi air sampai tumpah, sementara guru memosisikan diri sebagai yang mempunyai pengetahuan, sebagai satu-satunya sumber ilmu. Guru memberi ceramah dan menggurui, otoritas tertinggi adalah terletak pada guru. Penekanan yang berlebihan pada isi dan materi diajarkan secara terpisah-pisah. Materi pembelajaran matematika diberikan dalam bentuk jadi, dan semua itu terbukti tidak berhasil membuat siswa memahami dengan baik apa yang mereka pelajari. Penguasaan dan pemahaman siswa terhadap konsep-konsep matematika sangat lemah dan tidak mendalam. Akibatnya, prestasi belajar matematika siswa rendah. 
Pendidikan matematika, seyogianya diselenggarakan bukan dalam paksaan, yang siswa tidak tahu arah ke mana pembelajaran matematika dibawa. Sudah semestinya, pembelajaran matematika diselenggarakan dengan pendekatan humanis. Salah satu pendekatan humanis yang dapat diimplementasikan adalah menggunakan paradigma pembelajaran berdasarkan teori kecerdasan majemuk yang digagas Gardner. Gardner (1993) mengenalkan Teori kecerdasan majemuk yang menyatakan bahwa kecerdasan meliputi sembilan kecerdasan. Yaitu, kecerdasan linguistik, kecerdasan matematis-logis, kecerdasan visual, kecerdasan musik, kecerdasan kinestetik jasmani, kecerdasan interpersonal, kecerdasan intrapersonal, dan kecerdasan naturalis. Kemudian tahun 1999, Gardner menemukan jenis kecerdasan baru, kecerdasan kesembilan dalam teorinya, yang ia namakan kecerdasan eksistensial.

Ikhtiar melaksanakan pembelajaran matematika yang diusung dari penghargaan terhadap kecerdasan majemuk yang dimiliki masing-masing siswa, diharapkan dapat berimplikasi pada pelaksanaan pembelajaran yang humanis. Dengan demikian, siswa memiliki semangat belajar dengan penuh kesadaran, yang pada akhirnya dapat menuai prestasi di tingkat nasional bahkan internasional. Konsekuensi dari hal ini adalah, siswa belajar dengan nyaman, siswa mampu berprestasi, yang akhirnya siswa memiliki daya saing tinggi, sehingga siswa memiliki tingkat percaya diri yang tinggi dalam menghadai pemberlakuan Masyarakat Ekonomi Asean (MEA).

\section{Hakikat Pembelajaran Matematika dan Permasalahannya}

Dalam berbagai literatur disebutkan, matematika merupakan ilmu universal yang mendasari perkembangan teknologi modern, mempunyai peran penting dalam berbagai disiplin dan mengembangkan daya pikir manusia. Perkembangan pesat di bidang teknologi informasi dan komunikasi dewasa ini, dilandasi oleh perkembangan matematika di bidang teori bilangan, aljabar, analisis, teori peluang dan matematika diskrit. Untuk menguasai dan mencipta teknologi di masa depan salah satunya diperlukan penguasaan matematika yang kuat sejak dini.

Atas dasar hal tersebut, maka pelajaran matematika menjadi perlu diberikan kepada semua peserta didik mulai dari sekolah dasar (SD) untuk membekali peserta didik dengan kemampuan berpikir logis, analitis, sistematis, kritis, dan kreatif, serta kemampuan bekerjasama. Kompetensi tersebut diperlukan agar peserta didik dapat memiliki kemampuan memperoleh, mengelola, dan memanfaatkan informasi untuk bertahan hidup pada keadaan yang selalu berubah, tidak pasti, dan kompetitif.

Sejak peradaban manusia bermula, matematika memainkan peranan yang sangat vital dalam kehidupan sehari-hari. Berbagai bentuk simbol, rumus, teorema, dalil, ketetapan, serta konsep digunakan untuk membantu perhitungan, pengukuran, penilaian, peramalan, dan 
lainnya. Maka, tidak heran jika peradaban manusia berubah dengan pesat karena ditunjang dengan partisipasi matematika yang selalu mengikuti perubahan dan perkembangan zaman.

Matematika merupakan subjek yang sangat penting dalam sistem pendidikan di seluruh dunia. Akibatnya, bagi negara yang mengabaikan pendidikan matematika sebagai prioritas utama, akan tertinggal dari kemajuan segala bidang (terutama iptek), dibanding dengan negara lain yang memberikan tempat bagi matematika sebagai subjek vital. Di Indonesia, sejak bangku SD, SMP, SMA, hingga PT, bahkan mungkin sejak play group, syarat penguasaan terhadap matematika jelas tidak bisa dikesampingkan. Untuk dapat menjalani pendidikan selama di bangku sekolah sampai kuliah dengan baik, maka anak didik dituntut untuk dapat menguasai matematika dengan baik pula.

Satu hal yang penting untuk diketahui dan dijadikan pegangan adalah bahwa matematika itu merupakan ilmu dasar dari pengembangan sains dan sangat berguna dalam kehidupan sehari-hari. Dalam perdagangan kecil-kecilan saja, orang dituntut untuk mengerti aritmetika minimal penjumlahan dan pengurangan. Bagi pegawai/karyawan perusahaan harus mengerti waktu/jam, bendaharawan suatu perusahaan harus memahami seluk beluk perhitungan keuangan. Ahli agama, politikus, ekonom, wartawan, petani, ibu rumah tangga, dan semua manusia dituntut menyenangi matematika yang kemudian berupaya untuk belajar dan memahaminya, mengingat begitu pentingnya dan banyaknya peran matematika dalam kehidupan manusia.

Ada lima tujuan yang mendasar dalam belajar matematika seperti dirumuskan oleh NCTM (1990), yakni: That they learn to value mathematics; That they become confident in their ability to do mathematics; That they become mathematical problem-solvers; That they learn to communicate mathematically; dan That they learn to reason mathematically. Secara umum, tujuan diberikannya matematika di sekolah adalah untuk memenuhi kebutuhan praktis dan memecahkan masalah dalam kehidupan sehari-hari, mempersiapkan diri siswa agar sanggup menghadapi perubahan kehidupan dan dunia yang selalu berkembang dan sarat perubahan, melalui latihan bertindak atas dasar pemikiran logis, rasional, dan kritis. Begitu juga, untuk mempersiapkan siswa agar dapat bermatematika dalam kehidupan sehari-hari, mempelajari ilmu pengetahuan, teknologi dan seni (IPTEKS). (Suherman, 2001:56).

Pertanyaan yang sering muncul adalah, apa yang perlu dilakukan agar pembelajaran matematika di sekolah dapat memotivasi siswa untuk belajar matematika dan mampu mendidik para siswa sehingga mereka bisa tumbuh menjadi orang-orang yang mampu berpikir secara mandiri dan kreatif, berkepribadian mandiri, dan mempunyai kemampuan dan keberanian dalam menghadapi masalah-masalah dalam kehidupan mereka? Jika pembelajaran matematika di sekolah-sekolah kita dapat mengupayakan terbentuknya siswa dengan karakteristik seperti itu, berarti pembelajaran matematika di sekolah-sekolah kita telah 
memberikan sumbangan yang besar dalam meningkatkan kualitas sumber daya manusia Indonesia.

Akan tetapi, sejauh mana tujuan pendidikan matematika di sekolah sudah dapat direalisasikan. Inilah kiranya yang masih menjadi keprihatinan kita bersama. Sungguh banyak kesulitan yang ada dan merambah hampir ke seluruh komponen pembelajaran matematika, mulai dari faktor intern (siswa, guru, kurikulum, sarana dan prasarana yang belum memadai), sampai pada faktor ekstern (pentingnya peran orang tua dan lingkungan).

Terdapat beberapa hal, apabila kita mencermati praktik pembelajaran matematika yang kebanyakan masih dianut oleh lembaga penyelanggara pendidikan (sekolah) hingga akhir-akhir ini, di antaranya adalah:

a. Komposisi materi pembelajaran yang harus dipelajari siswa sangat padat, sedangkan alokasi waktu yang disediakan sangat terbatas.

b. Proses pelaksanaan pembelajaran lebih didominasi oleh upaya untuk menyelesaikan materi pembelajaran dalam waktu yang tersedia, dan kurang adanya proses dalam diri siswa untuk mencerna materi secara aktif dan konstruktif

c. Orientasi akhir pembelajaran yang cenderung hanya memenuhi kepentingan pragmatis, yakni untuk memenuhi target kulusan siswa dalam ujian nasional (UN).

d. Minimnya mengaitkan materi dengan kehidupan dunia nyata.

Berdasarkan beberapa hal di atas, maka dapat dikatakan bahwa pembelajaran matematika di Indonesia -sampai saat ini- belum mampu mengaktualisasikan potensi-potensi yang dimiliki oleh matematika pada diri siswa untuk memenuhi tujuan pembelajaran matematika. Untuk mengupayakan agar pembelajaran matematika di sekolah-sekolah dapat mengaktualisasikan potensi-potensi yang dimiliki oleh matematika pada diri para siswa, banyak hal yang perlu dilakukan, antara lain penggunaan kurikulum yang fleksibel, penerapan strategi pembelajaran yang lebih memberikan kesempatan pada siswa untuk mempelajari matematika secara aktif dan konstruktif, dan upaya untuk lebih melibatkan dunia nyata dalam proses pembelajaran matematika di sekolah.

Terkait upaya menyelenggarakan praktik pembelajaran matematika di sekolah di atas, melalui tulisan ini penulis akan menawarkan penyelenggaraan praktik pembelajaran matematika berbasis kecerdasan majemuk, yakni teori kecerdasan yang digagas oleh seorang ahli, Howard Gardner. Penerapan pembelajaran dengan menggunakan pendekatan kecerdasan majemuk ini diharapkan siswa dapat belajar secara bermakna. Dengan kata lain, siswa dapat mempelajari matematika dengan mengoptimalkan potensi kecerdasan yang dimilikinya. Akibatnya, siswa menjadi lebih senang dan bersemangat dapat belajar dan tentu akan membawa implikasi positif bagi tercapainya tujuan pembelajaran matematika di sekolah. Selanjutnya, di bawah ini penulis akan memaparkan dulu hakikat teori kecerdasan majemuk. 


\section{Teori Kecerdasan Majemuk}

Pada prinsipnya, tidak ada dua individu yang memiliki kecerdasan sama. Suatu individu mengaku belajar lebih baik dengan satu cara tertentu, sebagian yang lain mengaku bisa belajar dengan cara yang lain pula. Setiap orang memiliki gaya belajar yang unik. Tidak ada suatu gaya belajar yang lebih baik atau lebih buruk daripada gaya belajar yang lain. Tidak ada individu yang berbakat atau tidak berbakat. Setiap individu secara potensial pasti berbakat - tetapi ia mewujud dengan cara yang berbeda-beda. Tidak ada individu yang pintar, individu yang bodoh. Ada individu yang cerdas secara logika-matematika, namun ada juga individu yang cerdas di bidang kesenian. Pandangan-pandangan baru yang bertolak dari teori Howard Gardner mengenai inteligensi ini telah membangkitkan gerakan baru pembelajaran, antara lain dalam hal melayani keberbedaan gaya belajar pebelajar. Suatu cara pandang baru inilah yang mengakui ke-unik-an setiap individu manusia.

Menurut Suparlan (2007) manusia itu diciptakan unik. Tidak seorang pun manusia di dunia ini yang diciptakan sama, meski kembar sekalipun. Inilah yang sejak lama dalam ilmu pendidikan dikenal dengan konsep perbedaan individual (individual differences). Oleh karena itu, sistem klasikal sebenarnya tidak sesuai dengan konsep perbedaan individual, karena sistem klasikal menganggap semua siswa yang ada di kelas itu dalam banyak aspek dipandang homogen (sama).

Lebih lanjut Suparlan menyebutkan bahwa kondisi ini lebih diperparah lagi dengan penggunaan metode ceramah dalam proses belajar mengajar. Dengan metode ceramah, materi yang diajarkan sama, prasyarat kemampuan yang dimiliki siswa (prerekuisit) siswa dianggap sama, tugas-tugas yang diberikan kepada siswa juga sama, dan media dan alat peraga yang digunakan juga sama. Akhirnya, hasil akhir pengetahuan, sikap, dan keterampilan atau yang disebut sebagai tujuan instruksional yang diharapkan juga sama. Bahkan tes hasil belajar yang digunakan untuk mengukur kompetensi siswa juga sama. Itulah karakteristik sistem klasikal dalam proses pembelajaran.

Pelaksanaan sistem itulah yang kemudian memperoleh kritik dari banyak pakar yang berpihak kepada sistem pendidikan individual. Salah satunya adalah Howard Gardner, seorang professor ilmu syaraf (neurology) dari Universitas Harvard pada tahun 1984 (Suparlan, 2004:198). Howard Gardner mengubah pendapat itu dengan menyatakan bahwa kecerdasan tidak bersifat tunggal. Kecerdasan ada beraneka ragam. Dan setiap orang, termasuk anak-anak, memiliki karakteristik kecerdasan yang berbeda-beda. Ada 8 (delapan) jenis kecerdasan menurut Gardner, yaitu:

\section{1) Kecerdasan Linguistik}

Kemampuan untuk menggunakan bahasa untuk mendeskripsikan kejadian, membangun kepercayaan dan kedekatan, mengembangkan argumen logika dan retorika, atau mengungkapkan ekspresi dan metafora. Beberapa jenis pekerjaan yang membutuhkan 
kecerdasan linguistik adalah wartawan dan reporter, tenaga penjual, penyair, copywriter, penulis dan pengacara.

\section{2) Kecerdasan Logis-Matematis}

Kemampuan menggunakan angka-angka untuk menghitung dan mendeskripsikan sesuatu, menggunakan konsep matematis, menganalisa berbagai permasalahan secara logis, menerapkan matematika pada kehidupan sehari-hari, peka terhadap pola tertentu, serta menelaah berbagai permasalahan secara ilmiah. Beberapa jenis pekerjaan yang membutuhkan kecerdasan logika matematika adalah: akuntan, ahli statistik, insinyur, penemu, pedagang, dan pembuat program komputer

3) Kecerdasan Musikal

Kemampuan untuk mengerti dan mengembangkan teknik musikal, merespon terhadap musik, menggunakan musik sebagai sarana untuk berkomunikasi, menginterpretasikan bentuk dan ide musikal, dan menciptakan pertunjukan dan komposisi yang ekspresif. Beberapa jenis pekerjaan yang membutuhkan kecerdasan musikal adalah guru musik, pembuat instrumen atau alat musik, pemain band atau konduktor, DJ, kritikus musik, kolektor musik, pencipta lagu atau penyanyi.

\section{4) Kecerdasan Spasial}

Kemampuan untuk mengenali pola ruang secara akurat, menginterpretasikan ide grafis dan spasial serta menerjemahkan pola ruang secara tepat. Beberapa jenis pekerjaan yang membutuhkan kecerdasan spasial adalah photographer, dekorator ruang, perancang busana, arsitek, pembuat film.

\section{5) Kecerdasan Kinestetik}

Kemampuan untuk menggunakan seluruh atau sebagian dari tubuh untuk melakukan sesuatu, membangun kedekatan untuk mengkonsolidasikan dan meyakinkan serta mendukung orang lain, dan menggunakannya untuk menciptakan bentuk ekspresi baru. Beberapa jenis pekerjaan yang membutuhkan kecerdasan ini adalah mekanik, pelatih, pengrajin, atlet, aktor, penari atau koreografer.

\section{6) Kecerdasan Interpersonal}

Kemampuan untuk mengorganisasikan orang lain dan mengkomunikasikan secara jelas apa yang perlu dilakukan, berempati kepada orang lain, membedakan dan menginterpretasikan berbagai jenis komunikasi dengan orang lain, dan memahami intensi, hasrat, dan motivasi orang lain. Beberapa jenis pekerjaan yang menggunakan kecerdasan interpersonal adalah manajer, politisi, pekerja sosial, pemimpin, psikolog, guru atau konsultan. 


\section{7) Kecerdasan Intrapersonal}

Kemampuan untuk menilai kekuatan kelemahan, bakat, ketertarikan diri sendiri serta menggunakannya untuk menentukan tujuan, menyusun dan mengembangkan konsep dan teori berdasarkan pemeriksaan ke dalam diri sendiri, memahami perasaan, intuisi, temperamen, dan menggunakannya untuk mengekspresikan pandangan pribadi. Beberapa jenis pekerjaan yang menggunakan kecerdasan ini adalah perencana, pemuka agama, atau ahli filosofi.

\section{8) Kecerdasan Naturalis}

Kemampuan untuk mengenali dan mengelompokkan dan menggambarkan berbagai macam keistimewaan yang ada di lingkungannya. Beberapa pekerjaan yang membutuhkan kecerdasan naturalis ini adalah ahli biologi atau ahli konservasi lingkungan.

\section{Implikasi Teori Kecerdasan Majemuk dalam Pembelajaran Matematika}

Chatib (2009:100) memaparkan dalam bukunya yang berjudul "Sekolahnya Manusia", bahwa dalam faktanya, banyak siswa mengalami kebingungan dalam menerima pelajaran karena tidak mampu mencerna materi yang diberikan oleh guru. Ternyata, banyaknya kegagalan siswa mencerna informasi dari gurunya disebabkan oleh ketidaksesuaian gaya mengajar guru dengan gaya belajar siswa. Sebaliknya, apabila gaya mengajar guru sesuai dengan gaya belajar siswa, semua pelajaran (termasuk pelajaran matematika) akan terasa sangat mudah dan menyenangkan. Guru juga senang karena punya siswa yang semuanya cerdas dan berpotensi untuk sukses pada jenis kecerdasan yang dimilikinya.

Pada dasarnya setiap anak dianugerahi kecerdasan logis-matematis. May Lwin, dkk (2008:43) mendefinisikan kecerdasan logis-matematis adalah kemampuan untuk menangani bilangan dan perhitungan, pola, dan pemikiran logis dan ilmiah. Dapat diartikan juga sebagai kemampuan menyelesaikan masalah yang berkaitan dengan kebutuhan matematika sebagai solusinya. Anak dengan kemampuan ini akan senang dengan rumus dan pola-pola abstrak. Tidak hanya pada bilangan matematika, tetapi juga meningkat pada kegiatan yang bersifat analitis dan konseptual. Menurut Gardner ada kaitan antara kecerdasan matematik dan kecerdasan linguistik. Pada kemampuan matematika, anak menganalisis atau menjabarkan alasan logis, serta kemampuan mengkonstruksi solusi dari persoalan yang timbul. Kecerdasan linguistik diperlukan untuk menjabarkannya dalam bentuk bahasa.

Dalam paradigma belajar, siswa diposisikan sebagai subyek. Pengetahuan bukan sesuatu yang sudah jadi, tapi suatu proses yang harus digeluti, dipikirkan, dan dikonstruksi oleh siswa, tidak dapat ditransfer kepada mereka yang hanya menerima secara pasif. Dengan demikian, siswa sendiri-lah yang harus aktif. Paradigma belajar ini juga se-ide dengan teori 
Realistic Mathematics Education (RME) yang dikembangkan oleh Freudential, bahwa pengetahuan matematika dikreasi, bukan ditemukan sebagai sesuatu yang sudah jadi.

Oleh karena itu, siswa harus secara aktif mengkreasi dan mengkreasi kembali pengetahuan yang ingin dimilikinya. Tugas guru bukan lagi aktif mentransfer pengetahuan, tetapi bagaimana menciptakan kondisi belajar dan merencanakan jalannya pembelajaran dengan materi yang sesuai dan representatif, serta realistik bagi siswa sehingga siswa memperoleh pengalaman belajar yang optimal.

Keberhasilan dalam belajar matematika bergantung kepada proses belajar matematika. Dalam proses belajar matematika ini terjadi peristiwa belajar yang tidak hanya mengandalkan aspek kognitif saja, melainkan juga hubungan emosional dan sosial antara guru dengan siswa. Ini berarti kuat tidaknya interaksi sosial dan emosional guru dengan siswa akan menentukan keberhasilan belajar. Tidak dapat dijamin bahwa interaksi guru dan siswa yang tinggi akan menghasilkan keberhasilan belajar yang baik. Demikian pula tidak dapat begitu saja mengatakan interaksi guru dan siswa yang rendah akan menghasilkan prestasi yang jelek. (Hudojo, 2005:17). Banyak variabel yang mempengaruhi keberhasilan dalam proses belajar. Di antaranya dipengaruhi oleh gaya belajar siswa dan dominasi kecerdasan yang dimiliki masing-masing siswa. Dengan perbedaan kecerdasan inilah yang dapat berpengaruh terhadap gaya belajar sehingga berpengaruh pula terhadap hasil belajarnya.

Gaya belajar dapat menentukan prestasi belajar anak. Jika diberikan strategi yang sesuai dengan gaya belajarnya, anak dapat berkembang dengan lebih baik. Gaya belajar otomatis tergantung dari orang yang belajar. Artinya, setiap orang mempunyai gaya belajar yang berbeda-beda. Gaya belajar tidak bersifat kaku. Meski sudah memiliki gaya belajarnya bukan berarti siswa tidak bisa mengembangkan metode belajar yang lain. Jadi, ukuran keberhasilan paling penting adalah jika anak bisa menangkap informasi yang kita sampaikan dan menikmati aktivitas belajarnya.

Dengan menerapkan proses pembelajaran matematika yang didasarkan atas multilple intelligences, maka akan ada beragam profil gaya belajar siswa dalam kegiatan pembelajaran, yaitu:

(a) Siswa yang belajar matematika dengan menggunakan kecerdasan Linguistik.

(b) Siswa yang belajar matematika dengan menggunakan kecerdasan Matematis.

(c) Siswa yang belajar matematika dengan menggunakan kecerdasan Visual-Spasial.

(d) Siswa yang belajar matematika dengan menggunakan kecerdasan Musikal.

(e) Siswa yang belajar matematika dengan menggunakan kecerdasan Kinestetis.

(f) Siswa yang belajar matematika dengan menggunakan kecerdasan Interpersonal.

(g) Siswa yang belajar matematika dengan menggunakan kecerdasan Intrapersonal.

(h) Siswa yang belajar matematika dengan menggunakan kecerdasan Naturalis. 


\section{SIMPULAN DAN SARAN}

Implikasi dari penerapan multiple intelligences dalam pembelajaran matematika adalah terwujudnya gaya mengajar guru yang menyesuaikan dengan gaya belajar siswa. Bobbi DePorter, Mark Reardon, dan Sarah Singer-Nourie (2000:85-86) menjelaskan bahwa setiap orang memiliki kecenderungan gaya mengajar atau modalitas mengajar yang biasanya sama dengan gaya belajar masing-masing. Jika kita memiliki kecenderungan belajar secara visual, maka kita cenderung akan menjadi guru yang visual pula. Hal itu terjadi secara alamiah. Tetapi, tidak demikian dengan siswa. Sebagian mungkin memiliki gaya belajar yang sama dengan gurunya, tetapi mungkin banyak yang tidak. Bagi siswa yang modalitasnya tidak sama dengan modalitas mengajarnya guru, kemungkinan tidak akan dapat menangkap semua yang diajarkan atau mendapat tantangan lebih besar dalam mempelajari bahan.

Hasil yang diperoleh, dengan mengoptimalkan gaya belajar yang dipengaruhi oleh tingkat multiple intelligences, siswa dapat terlibat secara aktif dalam proses pembelajaran matematika, siswa lebih dapat menunjukkan kelebihan dan keunikan yang dimilikinya sehingga siswa merasa lebih dihargai yang akhirnya dapat meningkatkan kepercayaan diri dan menimbulkan rasa tanggungjawab siswa dalam $m$ proses pembelajaran matematika.

\section{DAFTAR RUJUKAN}

Chatib, Munif. 2009. Sekolahnya Manusia: Sekolah Berbasis Multiple Intelligence di Indonesia. Bandung: Kaifa.

DePorter, B., Mark R., \& Sarah S.N. 1999. Quantum Teaching:Orchestrating Student Success. Terjemahan oleh Ary Nilandari (Quantum Teaching: Mempraktikkan Quantum Learning di Ruang-Ruang Kelas). 2007. Bandung: Kaifa.

Gardner, H. 1993. Multiple Intelligences: The Theory in Practice. New York: BasicBooks.

Hudojo, H. 2005. Perubahan Paradigma Mengajar ke Belajar Matematika. Dalam Kapita Selekta Pembelajaran Matematika. Malang: t.p.

Lwin, M. 2008. How to Multiply Your Child's Intelligence. Terjemahan oleh Christine Sujana (Cara Mengembangkan Berbagai Komponen Kecerdasan). 2008. Bandung: PT. Indeks.

Murtiyasa, Budi. 2015. Tantangan Pembelajaran Matematika Era Global. Prosiding Seminar Nasional Matematika dan Pendidikan Matematika UMS, 10 Mei 2015. Surakarta: Universitas Muhammadiyah Surakarta.

Suherman, Erman, dkk. 2001. Strategi Pembelajaran Matematika Kontemporer. Bandung: JICAUniversitas Pendidikan Indonesia.

Suparlan. 2004. Mencerdaskan Kehidupan Bangsa: Dari Konsepsi Sampai dengan Implementasi. Yogyakarta: Hikayat.

Suparlan. 2007. Kecerdasan Ganda (Multiple Intelligences): Penerapannya dalam Proses Pembelajaran dan Pengajaran, (Online), (http://suparlan.com, diakses 15 Desember 2008). 